\title{
A RAPID HEALTH IMPACT ASSESSMENT OF THE UNIVERSITY OF ILORIN DAM
}

\author{
S. O. Bilewu ${ }^{1}$, A. M. Ayanshola ${ }^{2,}{ }^{*}$ and A. W. Salami ${ }^{3}$ \\ 1,2,3 DEPT. OF WATER RESOURCES AND ENVIRONMENTAL ENGR., UNIV. OF ILORIN, ILORIN, KWARA STATE. NIGERIA \\ Email addresses: ${ }^{1}$ bilewuk@yahoo.com, ${ }^{2}$ engramayanshola@gmail.com, ${ }^{3}$ awsalami2009@gmail.com
}

\begin{abstract}
Many Dams have been constructed in different parts of the world and for different purposes. While these dams have in most cases served the reason for their construction, the resultant environmental impact have been a subject of concern. The creation of a reservoir not only changes the ecology and hydrology of the environment, the lives of nearby residents is also affected. This study assessed the impact of the University of Ilorin Dam on the health condition of the University community. The Dam was built for the main purpose of water supply to university community. Data on the water related disease reported and documented at the university clinic was obtained to cover pre and post construction period while the perception and behavioral pattern of the community as related to water and sanitation was studied with the help of a structured questionnaire. The chi-squared test was applied to establish that a relationship do exist between the dam construction and the occurrence of some diseases especially Malaria. The study have also shown that the dam imposes no significant negative health impact on the university community.
\end{abstract}

Keywords: Dam, Reservoir, Diseases, Malaria, Prevalence

\section{INTRODUCTION}

Dams are structures built to retain water by forming a reservoir behind the structure. They are usually built across, or near naturally flowing water to manage the water for human use [1]. The first dams were built about 4000 BC. Many fairly old dams are still in use in different parts of the world. Examples include the Lake Homs Dam in Syria, constructed between 1319 and 1304 BC, the Proserpina and the Cornalvo Dams in Spain, both constructed in the second century $\mathrm{AD}$ and the Kaerumataike dam in Japan, built in 162 AD [2]. There are five main uses of Dams: hydro-electric power, irrigation, water supply, flood protection and navigation. All the Dams in the world, collectively hold about 7,000 $\mathrm{km}^{3}$ of water with a reservoir coverage area of about $500,000 \mathrm{~km}^{2}[1]$.

Every Dam causes temporary or permanent submergence and in some cases the displacement of persons and property [3]. Various studies of dam impact exists in literature. These studies covers the ecosystem changes [4], hydrology and river dynamics, physico chemical cycles, soil, water quality, environmental toxicity [5] and health [6, 7]. However, the result of various studies are site specific and show evidence of regional variations in health conditions because of construction of dams in different parts of the world [8]. Therefore, the main aim of this study is to rapidly assess the impact of the University of Ilorin dam on the health of the residents within the university space in order to scope a detailed health impact. Scoping is the process of identifying issues to be considered and selecting and developing the alternatives. This rapid assessment is meant to decide on what are the most relevant impacts, help to establish positive effects to be enhanced and negative effects to be mitigated.

The seasonal flow of water in many rivers in Nigeria has necessitated the storage of water for use during the periods of low or no flows. This is done with the construction of dams and other barriers. Large areas of land become inundated when dams are constructed and this sometimes affects the occurrence of water related diseases. The health impacts of Dams on human existence consist mainly of water related diseases. Water related disease is defined as any significant or widespread adverse effect on human health, such as death, disability, illness or disorders, caused directly or indirectly by the conditions, or changes in the quantity or quality of any waters [9]. These can be either waterborne such as cholera, typhoid, shigellosis, diarrhea, etc. [10]; or water based/water - related insect vectors such as malaria, schistosomiasis, filariasis, onchocerciasis or river blindness [11,12]. Morbidity and mortality rates of some water related diseases as given by the World Health Organization (WHO) shows diarrhea only resulted in over four million deaths in $1995[9,13]$. Studies in Africa and Asia has shown that malaria is a significant contributor to water related diseases [14]. Globally, between 300 and 500 million people are 
infected annually with malaria and the mortality rate is up to 2 million per year with Africa most affected [15, 16]. There are also reported cases of disease transmitted by the favourable conditions created by dam construction. Examples include the case of the Kariba Dam in Zambia, where those who were resettled in an area infested by tsetse fly, now suffer from a high incidence of sleeping sickness. Similarly, in Sri Lanka, those resettled under the Mahaweli scheme were moved to the infertile and malaria-infested plains of the dry zone. Inevitably, many succumbed to both malaria and malnutrition [17]. The occurrence of toxic algal bloom in the stagnant water of the reservoir, especially during the period of no flow is also a common sight. This is especially true where recreational contact with the water is allowed.

This assignment aims to assist environmental engineers in Environmental Impact Assessment (EIA) scoping and the structural mitigation of health hazards resulting from the construction of dams. A detailed EIA would often involve different professionals including Doctors, Chemists, Microbiologists, Socio-economic experts, Environmentalists, Agricultural experts and Engineers. The decision on who is to participate in a full EIA on a water resources project is site specific and can be taken based on a rapid assessment.

\section{METHOD AND MATERIALS}

\subsection{The Study Area}

The study Dam is located on the main campus of the University of Ilorin, Nigeria $\left(8.467^{\circ} \mathrm{N}, 4^{\circ .666^{\circ}} \mathrm{E}\right)$. The University is located at Ilorin South Local Government area of Kwara State (Figure 1). It was established in 1975, physical development of the structures commenced in 1979. The Dam, located on the Oyun River which flows through the campus is about $1.5 \mathrm{~km}$ from the halls of residence. It was constructed between 2005 and 2006. The dam essentially supplies raw water to a treatment plant for the supply of potable water to the University community. Before the water supply facility was constructed, the university depended on public water supply twice a week and sometimes on special requests. The reservoir has a full supply depth of about $5 \mathrm{~m}$ and a submerged area of about $650 \mathrm{~km}^{2}$. The treatment plant capacity is $100 \mathrm{~m}^{3} / \mathrm{hr}$. Based on the year 2013 annual report, the resident population served by the dam was 3,672 [18].

\subsection{Data Collection and Analysis}

The methodology adopted for this assignment is qualitative. Rapid assessments are carried out for scoping or because of shortage of time and money. The main requirement for such an assessment is that it should be simple, rapid and structured. It depends on secondary data and informal interviews [19]. Data on water related diseases was obtained from the University clinic which serves the university community exclusively. This data covers pre and post construction periods (2005 to 2008). The selected diseases were the only ones reported and documented at the clinic. Construction was mostly done in 2006. A total number of 460 questionnaires were administered to staff and students who reside on the university campus and are most likely to be most exposed to the effects of the dam. 351 was retrieved, which captured their perception and habits relating to water supply and sanitary practices. This sample size was determined using sample size calculator with the University community population of 3,672 [18] and a confidence level of 95\% (0.05) [20], a sample size of 348 was calculated. Data relating to the water treatment plant, Dam design and operation were obtained from the University's Works Department. There is no settlement in the immediate downstream of the dam to justify a further health assessment of the downstream. The health baseline indicators are two folds. The direct ones were essentially diseases whose data were collected from the clinic while the indirect determinants were documented by observation and questionnaire administration. Diseases documented include Malaria, Fever (typhoid, etc), upper respiratory tract infection (URTI), itching, dysentery, diarrhea and enteritis. The determinants observed include air quality, sanitary conditions, waste disposal, mosquitoes, swampy areas and drinking water sources. These determinants were observed because they have the tendency to impact on the occurrence of water related diseases to and may thus affect data interpretation relative to the presence of the Dam. The data collected was subjected to statistical test to determine the relationship that exists between the various parameters considered.

\section{RESULTS AND DISCUSSION}

Figures 2 to 5 shows the monthly variation of water related diseases reported at the university of Ilorin clinic during the study period. Figures for 2004 and 2005 were quite close and thus only 2005 figures were used for analysis. From the figures, malaria and fever (Typhoid, yellow etc) showed an increased incidence before and during construction. It is even more obvious during the rainy season in Ilorin which is usually between April and October each year. Other measured diseases like Cholera, were de-emphasized in this rapid analysis because they exhibit insignificant variation pre and post dam construction and they can be caused through other means apart from the University Dam. 
Malaria occurrence post-construction seems to defy the expectation of a higher raining season prevalence. In the years before the dam construction, (year 2005) malaria and fever prevalence tend to follow seasonal rainfall variations. Malaria and fever increased and reduced with rainfall events. After dam construction, seasonal variation with diseases became less significant. This may be as a result of the reservoir created by the dam which enables mosquitoes to breed for longer periods annually as water stagnation increased.
Health impact estimation may be influenced by mosquito dispersal distance. Established flight distances for some mosquito species include $3 \mathrm{~km}$ (Aedes), $3.5 \mathrm{~km}$ (Anopheles) and $5 \mathrm{~km}$ (Culex) [21]. Residential buildings are about $1-1.5 \mathrm{~km}$ from the University Dam and the short range dispersion of mosquitoes is influenced by the environment and environmental changes. The range of air temperature in Ilorin $\left(19-36^{\circ} \mathrm{C}\right)$ is suitable for a good dispersal. Mosquito flight is reduced by low temperature [22] and high wind [23]. The residences are thus within the flight distance of the mosquitoes.

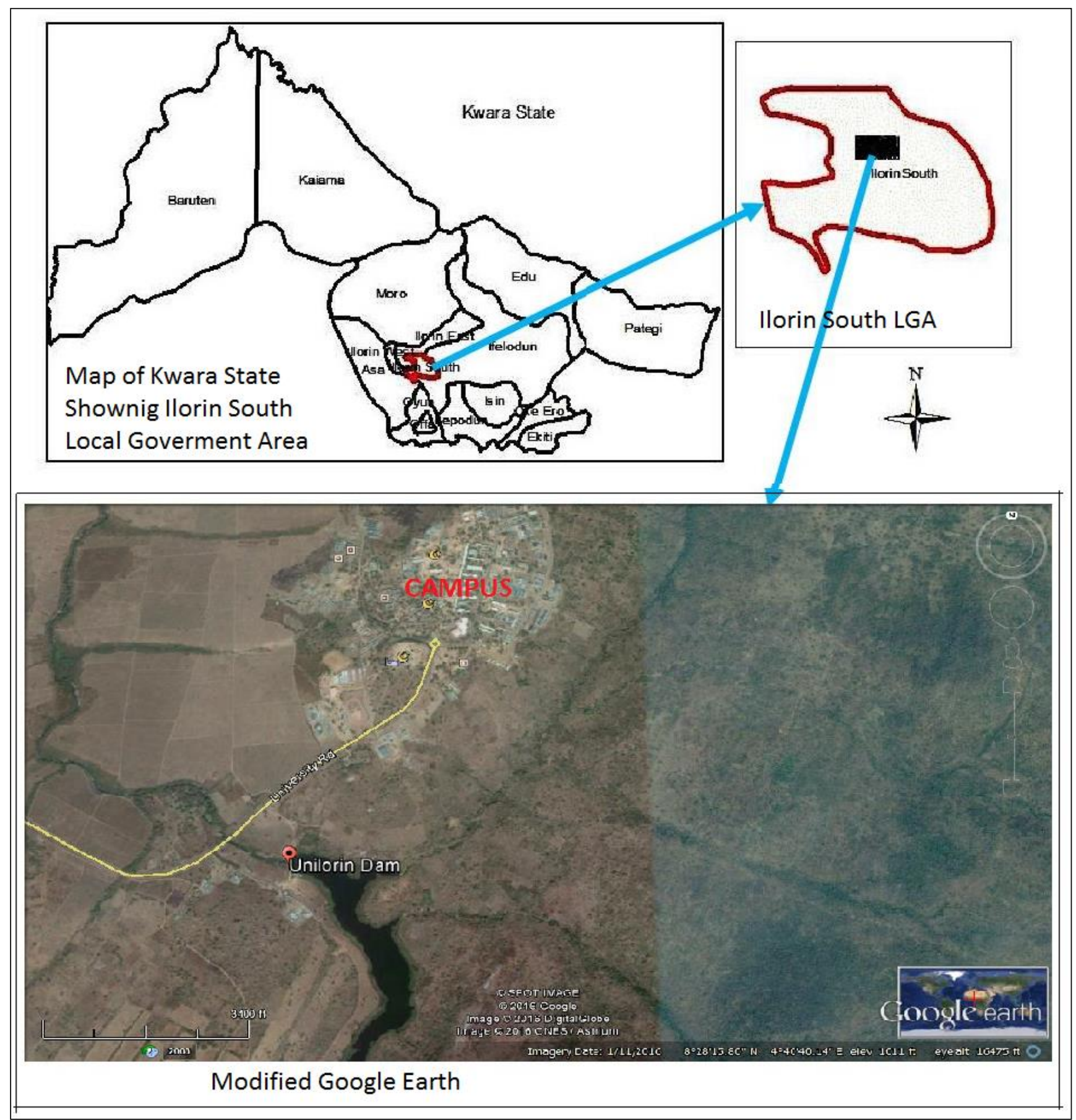

Figure 1: Map of Kwara State and Modified Google Earth Showing the Study Area 


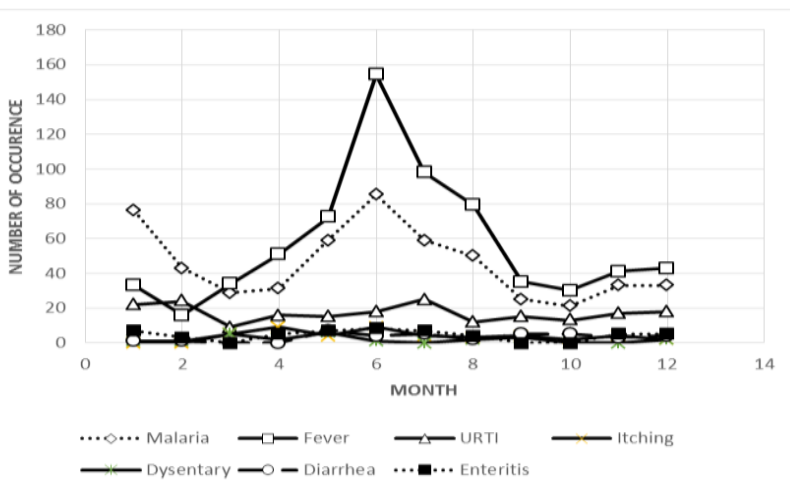

Figure 2: Monthly Disease Occurrence Reported at the University of Ilorin Clinic in 2005

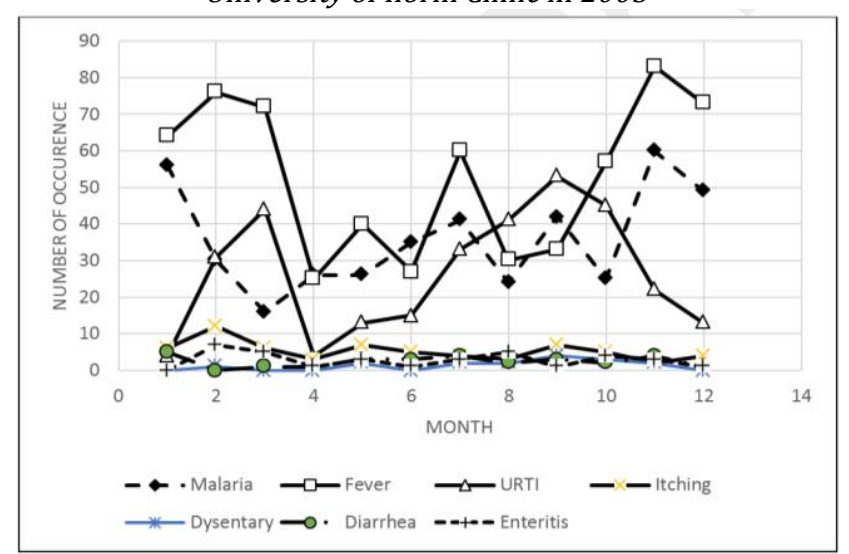

Figure 4: Monthly Disease Occurrence Reported at the University of Ilorin Clinic in 2007

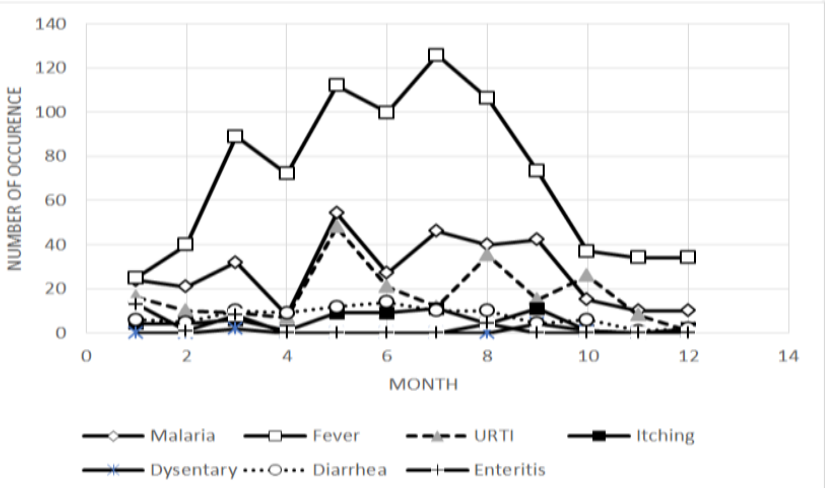

Figure 3: Monthly Disease Occurrence Reported at the University of Ilorin Clinic in 2006

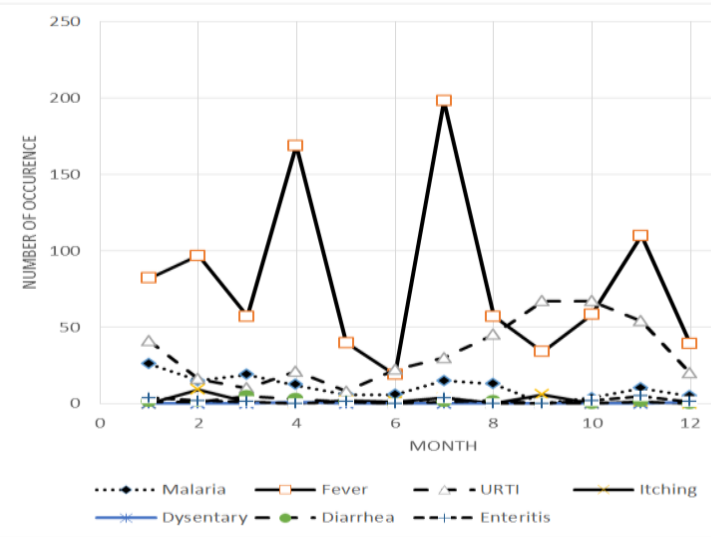

Figure 5: Monthly Disease Occurrence Reported at the University of Ilorin Clinic in 2008

Table 1: Monthly Average of Water Related Diseases Reported at the University of Ilorin Clinic

\begin{tabular}{lccccccc}
\hline Year & Malaria & Fever & URTI & Itching & Dysentary & Diarrhea & Enteritis \\
\hline 2005 & 45 & 57 & 17 & 4 & 2 & 3 & 4 \\
2006 & 27 & 71 & 17 & 5 & 1 & 2 & 2 \\
2007 & 36 & 53 & 27 & 5 & 1 & 3 & 2 \\
2008 & 11 & 80 & 33 & 2 & 0 & 2 \\
\hline
\end{tabular}

Table 1 and figures 6 and 7 show the monthly average of water related diseases reported at the University of Ilorin clinic for the study years. This gave a fair indication of the prevalence of these diseases. There is a general reduction in the occurrences of malaria, dysentery, diarrhea, enteritis and itching. It is however not possible to attribute this to the presence of the Dam only. These diseases can also be spread through bad sanitation practices and food consumption. It is to be noted that consequent upon the Dam construction, a water treatment facility was also completed. This probably explains the fall in the diseases in figure 7. These are disease related to food, drinks and general sanitation too. The data in Table 1 was subjected to the chi - square test to test if indeed a relationship exists between the disease occurrence and the years. The null hypothesis is that no relationship exists between these categorical variables and that they are independent. The test was first performed on the malaria, fever and URTI data for the study years. With 4 degrees of freedom, the chi - square statistic is 10.69 , the $\mathrm{p}-$ value is 0.03023 at $95 \%$ confident interval. Since the $\mathrm{p}$ - value is less than the significant level, it is reasonable to conclude that there is a relationship between the dam construction and the occurrence of these diseases and it is positive as shown in figure 6. Of the three diseases considered here, malaria is the one most related to the presence of the dam reservoir. The dam also ensured the water security of the University community with the provision of raw water to the water treatment plant. However, fevers and URTI are also frequently reported at almost the same level as malaria.

When the chi - square test was applied to the other diseases (itching, dysentery, diarrhea and enteritis), the result gave a chi-statistic of 4.02 and a p-value of 0.6737 significant to 0.05 . This indicates that there is no relationship between these diseases and the dam construction. This is consistent with the fact that these set of diseases are water borne diseases that are also influenced mainly by food and water consumption and sanitation conditions and not necessarily by the reservoir created. 


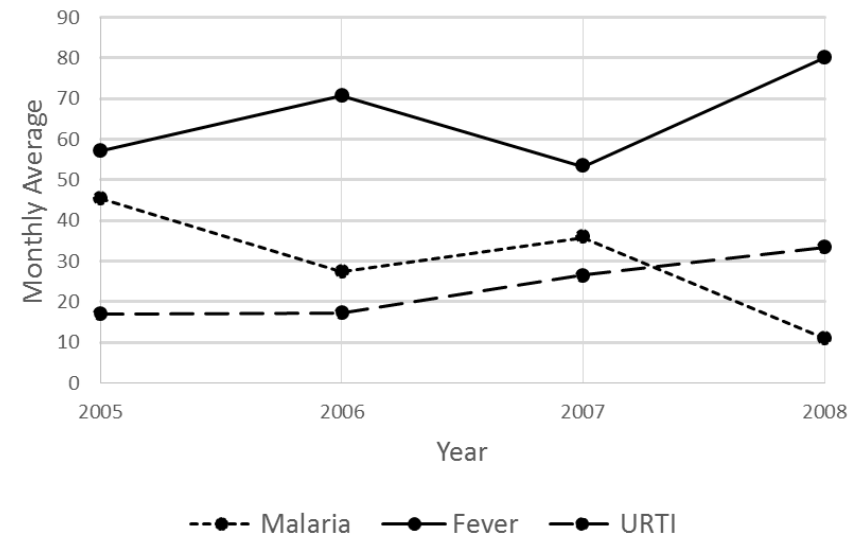

Figure 6: Monthly Average of Malaria, Fever and URTI Reported at the University of Ilorin Clinic from 2005 - 2008.

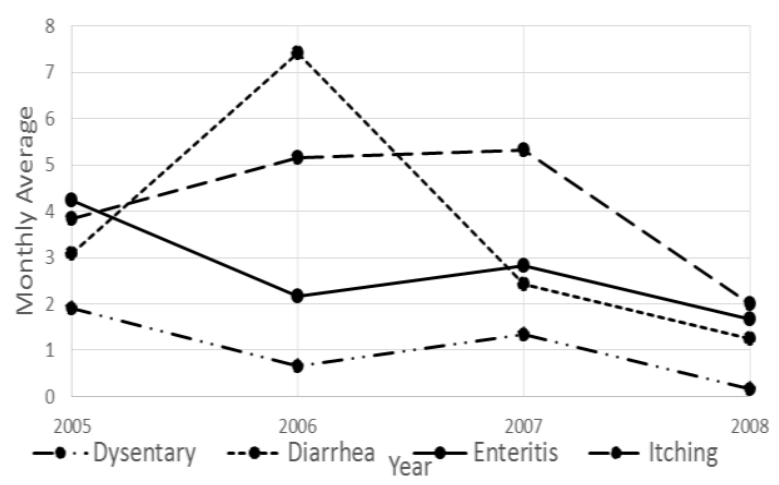

Figure 7: Monthly Average of Dysentery, Diarrhea, Enteritis and Itching Reported at the University of Ilorin Clinic from 2005 2008.

Table 2: Perception of the presence of Vectors $(n=54)$

\begin{tabular}{llc}
\hline SN & \multicolumn{1}{c}{ Vector } & $\begin{array}{c}\text { \% of Respondents that Acknowledged } \\
\text { Vector presence }\end{array}$ \\
\hline 1. & Mosquitoes & 70 \\
2. & Snail Vector & - \\
3. & House Flies & 20 \\
4. & Rat / Mice & 19 \\
5. & Snakes & 10 \\
& scorpions & \\
6. & Tse Tse flies & 11 \\
\hline
\end{tabular}

Having established that there is a relationship between the dam construction and disease prevalence, the local perception of illness and these diseases was checked. Tables 2 and 3 summarizes the result of the questionnaires administered. The presence of mosquitoes was perceived by $70 \%$ of the respondents as compared to other vectors, which gives some credence to the prevalence of malaria. Other vectors perceived (for example Rodents, Flies and Snail), though not directly related to the reservoir also aid the occurrence of water related diseases. Some behavioral practices, as in Table 3 , also influence disease occurrences. With $92 \%$ of the residents depending on pipe borne water for their domestic use, and a $100 \%$ return on hand - washing before eating, the possible transmission of water related diseases through this means is further reduced. $88 \%$ of respondents are daily exposed to mosquito bites and of these, $68 \%$ has no form of protection against bites. It is therefore reasonable to assume that the incidence of malaria reported at the clinic has not been significantly affected by malaria prevention activities.

It is possible that the development of water resources projects in the tropics can result in malaria epidemic during construction [17] as there is an increased number of ponding resulting from construction burrow pits, introduction of new strains of malaria and the disturbance of the social structure of the population. In this case, there is no evidence of a malaria epidemic during construction, or a new strain after construction. The social structure of the university did not change before, during or after the dam construction.

The global population living in close proximity of dam reservoirs in malaria endemic areas is about 18.3 million people. On the other hand as many as 851.3 million people live in or close to irrigation systems in malaria endemic areas. In sub-Saharan Africa, which has $87.9 \%$ of the estimated global malaria burden, only 9.4 million people live near large dam reservoirs and irrigation sites \{7\}. The university of Ilorin dam is not used for irrigation purposes and thus the malaria occurrence may be relatively lower.

Table 3: Behavioral Practices and the feeling of the Residents

\begin{tabular}{|c|c|c|}
\hline SN & Practice / Feeling & $\begin{array}{l}\% \text { of respondents that } \\
\text { Acknowledged the Practice / } \\
\text { Feeling }\end{array}$ \\
\hline 1. & $\begin{array}{l}\text { Water Source } \\
\text { Well } \\
\text { Pipe Borne Water } \\
\text { Stream / River } \\
\text { Pond / Reservoir } \\
\end{array}$ & $\begin{array}{c}8.0 \\
92.0 \\
- \\
- \\
\end{array}$ \\
\hline 2. & $\begin{array}{lll}\begin{array}{l}\text { Washing Hand before } \\
\text { eating }\end{array} & \\
\end{array}$ & 100.0 \\
\hline 3. & $\begin{array}{lll}\begin{array}{l}\text { Contact with water } \\
\text { (Bathing) }\end{array} & \\
\end{array}$ & 100.0 \\
\hline 4. & $\begin{array}{l}\text { Exposure to Mosquito } \\
\text { bites }\end{array}$ & 88.0 \\
\hline 5. & $\begin{array}{l}\text { Protection } \\
\text { Mosquito Bites } \\
\text { Bed Nets } \\
\text { Coils } \\
\text { Insecticides } \\
\text { None }\end{array}$ & $\begin{array}{c}14 \\
- \\
8.0 \\
68.0\end{array}$ \\
\hline 6. & $\begin{array}{l}\text { Benefit of the Dam } \\
\text { Source of Drinking Water }\end{array}$ & 100 \\
\hline
\end{tabular}

\section{CONCLUSION}

The University of Ilorin Dam, since its construction in 2006, has continued to provide water for use on the campus. Apart from regulating the flow regime of the Oyun River, it has provided some storage reservoir. However, it has equally created some health impact. A relationship was established between the dam 
construction and the prevalence of some water related diseases, especially malaria. Apart from fever typhoid, cholera etc), the number of malaria and other water related diseases reported at the University Clinic have relatively reduced from the pre-construction years. It is thus reasonable to conclude that the construction of the University of Ilorin dam has not negatively impacted on the occurrence of the studied water related diseases.

\section{REFERENCES}

[1] British Dams Society (BDS). "Dams and Reservoirs", 2015. Accessed from www.britishdams.org/student zone on 15/10/2015.

[2] Water Technology.net. "The World's Oldest Dam still in Use", 2013.Accessed from www.water-technology.net on $18 / 09 / 2015$.

[3] International Commission on Irrigation and Drainage (ICID). "Role of Dams for Irrigation, Drainage and Flood Control". ICID Position Paper, 2000. Accessed from www.icid.org on 22/10/2015.

[4] Lin, Q. "Influence of Dams on River Ecosystem and its Countermeasures", Journal of Water Resources and Protection, Vol. 3, pp 60 - 66, 2011.

[5] Wildi, W. "Environmental Hazards of Dams and Reservoirs", NEAR Curriculum in Natural Environmental Science, Terre et Environment, Vol. 88, pp 187 - 197, 2010.

[6] Lerer, L. B. and Scudder, T. "Health Impacts of Large Dams", Environmental Impact Assessment Review, Vol. 19, pp 113 - 123, 1999.

[7] Keiser, J., De Castro, M. C., Maltese, M. F., Bos, R., Tanner, M., Singer, B. H., and Utzinger, J. "Effect of Irrigation and Large Dams on the Burden of Malaria on a Global and Regional Scale". American Journal of Tropical Health and Hygiene, Vol. 72, Number 4, pp 392 - 406, 2005.

[8] M Renshaw , M H Birley, D K Sang and J B Silver, "A rapid health impact assessment of the Turkwel Gorge hydroelectric dam and proposed irrigation project". Impact Assessment and Project Appraisal, Vol. 16, Number 3, pp 215-226, 1998

[9] World Health Organization (WHO). "Human Health and Dams, Protection of the Human Environment Water", Sanitation and Health Series, Geneva, 2000.

[10] Sojobi, A.O., Dahunsi, S.I. and Afolayan, A.O. "Assessment of the Efficiency of Disinfection Methods for Improving Water Quality", Nigerian Journal of Technology Vol. 34, No. 4, pp. 907-915, 2015.
[11] Griffiths, J. K. "Waterborne and Water Related Diseases Role of Water Treatment and Sanitation, Syndromes", Biology of Water and Health, Tufts University, USA, 2008.

[12] Goldsmith, E., and Hildyard, N. "The Social and Environmental Effects of Large Dams", Wadebridge Ecological Centre, UK, 1984.

[13] World Health Organization (WHO). "Water and Public Health. WHO Seminar Pack for Drinking Water Quality", 2005. Accessed from: www.who.int/water sanitation health/dwq/S01.pdf on 29/09/2015.

[14] Van der Hoek, W. "Human Health in Water Resources Development", Encyclopedia of Life Support Systems, Water and Health, Vol. 2, 2015.

[15] International Water Management Institute, (IWMI). "Dams and Malaria in Sub-Saharan Africa, Colombo, Sri Lanka", International water Management Institute (IWMI), IWMI Water Policy Brief 34, 8 pp, 2010.

[16] Orukpe, P.E. and Mohammed, A.O. "Fussy Control Technique Applied to Modified Mathematical Model for Malaria Control", Nigerian Journal of Technology, Vol. 34, No. 4, pp. 815-821, 2015.

[17] Tadesse, D., Mekonnen, Y. and Assmelash, T. "Adult Mosquito Populations and Their Health Impact around and far from Dams in Tigray Region, Ethiopia", Momona Ethiopian Journal of Science Vol. 4, Number 2, pp 40-51, 2012.

[18] University of Ilorin. "Year 2013 Annual Report of University of Ilorin", University of Ilorin, Nigeria, 2013

[19] Stanwell-Smith, R. "Classification of Water Related Diseases", Water and Health, Volume 1, 2001.

[20] Munn, P. and Drever, E. "Using questionnaires in small scale research: a teacher's guide", SCRE, Edinburgh, 1990.

[21] Hamer, G. L., Anderson, T. K., Donovan, D. J., Brawn, J. D., Krebs, B. L., Gardner, A. L., Ruiz, M. O., Brown, W. M., Kitron, U. D., Newman, C. M., Goldberg, T. L. and Walker, E. D. "Dispersal of Adult Culex Mosquitoes in an Urban West Nile Virus Hotspot: A Mark - Capture Study Incorporating Stable Isotope Enrichment of Natural Larval Habitats", PLOS Neglected Tropical Diseases, 8(3), e2768, 2014.

[22] Elbers, A. R. W., Koenraadt, C. J. M., Meiswinkel, R. "Mosquitoes and Culicoides biting Midges: Vector Range and the Influence of Climate Change", Revue Scientifique et Technique, International Office of Epizootics, Paris, Vol. 34, Number 1, pp 123 - 137, 2015.

[23] Gaines, D. N. "Mosquitoes, West Nile Virus, and Procedures Used for Mosquito Surveillance and Control", Virginia Department of Health, US, 2015. 